\title{
ENGLISH LESSONS IN LOWER SECONDARY SCHOOLS IN POLAND: REFLECTIONS BASED ON LEARNER VOICES
}

\section{English lessons in lower secondary schools in Poland: Reflections based on learner voices}

This paper reports on some of the data from a large-scale study Teaching and Learning Foreign Language in lower secondary school, which began in the school year 2011-12 and traces selected groups of learners through the three years of Key Stage 3 (gimnazjum), ending in school year 2013-14. The study was conceived and is managed by the Foreign Language Section of the Educational Research Institute (ERI) in Warsaw with European funding. (see Acknowledgement). In this article the focus is on data obtained from interviews conducted with learners from class one of 120 lower secondary schools, where the students were asked to describe and give opinions about learning English in their school and to imagine an ideal lesson. The learners are the reason that lessons in school take place, but their views are rarely consulted. This study attempts to redress the balance.

Key words: pupils' opinions, lower secondary, English lessons

Słowa kluczowe: opinie uczniów, gimnazjum, lekcje języka angielskiego

\section{Student Voice}

In mainstream education in the UK, the US, Australia, and Canada the concept of Student Voice began to gain popularity in the 1990's. Ruddock (2004:1 ) equates Student Voice with consulting pupils for their views: 
about things that matter in school. It may involve: conversations about teaching and learning; seeking advice from pupils about new initiatives; inviting comment on ways of solving problems that are affecting the teacher's right to teach and the pupil's right to learn; inviting evaluative comment on recent developments in school or classroom policy and practice.

Rudd et al. (2007:8) define giving students voice as "Empowering learners by providing appropriate ways of listening to their concerns, interests and needs in order to develop educational experiences better suited to those individuals." The main drive for this movement was the desire to change the role of young people from being passive recipients in the schooling process to becoming fuller partners. Kozol (1991:5), for example, noted that children are not consulted for their views on education or educational reform, despite the fact that they are its main users. The publication of the UN Convention on the Rights of the Child (1989) however, provided a lever for change. This states that children have the right to be heard and to be consulted on matters which impact on them and their welfare and was followed by legislation and educational policies to this effect in many countries.

\subsection{Reasons for giving learners the right to give opinions on education}

There are several reasons for involving students in discussions about education. Ruddock (2004:2) proposes that if learners become involved they have a sense that their opinion is valued and that they can influence decisions about issues which concern them, which in turn helps them to feel respected and listened to. Once learners become active in this way, their motivation for learning increases and dissatisfaction and dropout rates may decrease (Bragg 2007). At the same time, partnership in such a process helps young people develop important life-skills such as negotiation, taking the initiative, and cooperation, skills which they will need when they leave school and look for work. In addition there are personal benefits, such as increased self-esteem (Flutter and Ruddock 2004).

Another argument for listening to what learners have to say is that it offers opportunities for teachers to improve their practice. Ruddock and Flutter (2004), in extensive research with school children in the UK, found teachers listening to learner opinions were a key part of this process. On a larger scale there are also calls for learners to be involved in educational reform "Decades of calls for educational reform have not succeeded in making schools places where all young people want to and are able to learn. It is 
time to invite pupils to join the conversations about how we might accomplish that." (Cook-Sather, 2002:16)

Flutter and Rudduck (2004:131-132) echo this sentiment arguing that pupils are able to indicate ways in which their schools can change for the better.

\subsection{The right for pupils to voice opinions on education in Poland}

The culture of giving students voice is still young in Poland. The UN Convention on the Rights of the Child was ratified in Poland in 1991, followed by legislation on school statutes in 1992, which states that young people "may state their opinions in school, in classes or in the student council on the topic of school programmes, teaching methods and other issues which are of importance in school life." (MEN 1992: article 10, own translation). In research conducted by The Helsinki Foundation for Human Rights in 1995-6 it was found, however, that among approximately 3000 respondents $60 \%$ felt they could exercise this right, but only with regard to certain teachers, while only $14 \%$ agreed this applied to being able to give opinions about all the teaching staff. $23 \%$ of the sample were either undecided, or asserted that they could not give their opinions. (Czyż, Prawa ucznia w szkole: 150, own translation).

Asking learners to talk about the learning process is not common in foreign language education in Polish state schools. Although learners may have experience of being invited to complete questionnaires, being interviewed individually is much rarer, probably because of the time and effort involved. It was felt that the subjects of this study, learners aged 13-14, might find direct questions inviting them to be critical about their English lessons potentially difficult to answer, for the reason that they might be unsure of the anonymity of their responses and might fear a reaction from the teacher or school if they voiced negative feelings. Consequently learners were invited to fantasize about an ideal lesson. In this way, through the 'mask' of descriptions from the imagination they could be free to give opinions without fear of censure.

\section{Context of the research}

In 2011 the Educational Research Institute (ERI) in Warsaw began a three year study with the aim of investigating the effectiveness of teaching English in lower secondary schools in Poland. The research plans to gather information about how English is taught in state schools and to identify factors which have an impact on learning outcomes. A representative sample of 120 
schools (gimnazjum) were selected. Within the sample schools three groups of pupils learning English as a continuation from primary school, (level III.1 in the Core Curriculum), were nominated by the school to take part in the study. This gave a sample of approximately 4400 learners. From each school four students were randomly selected for interview, making a total of 480 students, aged between 13 and 14. Although this is a large sample the fact that the schools nominated the groups to take part means that at the level of the individual learner it is not representative.

The research design for the main study is based on the principle of triangulation, where data on the same area of interest is collected from different perspectives and from various respondents. These include questionnaires given to teachers and learners; observation of lessons; interviews with English teachers from each school and interviews with learners. Thus the extracts from interviews which will be described here are a fragment of a wider and more complex picture.

\section{Methodology}

Interviews with the learners were conducted according to a prepared script which covered several areas connected with teaching and learning. Polish was chosen as the language of the interview to enable learners to give full answers. The script was first piloted and adjustments made to the questions. The main research study was conducted by the firm Millward Brown $\mathrm{SMG} / \mathrm{KRC}$, who won the public tender for the project. For the interviews they recruited 54 people, who were then trained on a course run by members of the Foreign Language Section of ERI using films from the pilot and the script, with the aim of ensuring reliability in conducting the interviews .

The interviews, which lasted approximately 5 minutes each, were carried out between March and May 2012. Each interview was audio-recorded and these were then transcribed in the program $\mathrm{f} 4$ by a team of 10 transcribers. A team from ERI then prepared an initial code tree for analyzing the transcripts in the program Maxqda 10 and subsequently trained 24 coders. During the period in which the transcripts were being coded, an interactive forum allowed contact between the team members and made it possible for modifications to the code tree to be shared.

This paper focuses on learners' descriptions of their English lessons and aims to answer the following questions:

1. How do learners describe their typical English lessons? 
2. What is most frequently mentioned in learner descriptions of their typical English lessons?

3. When asked to talk about an ideal lesson of English which areas of the learning process are most frequently described?

4. How do learners describe their idealized teacher of English?

5. How do learners describe their idealized learning group?

In order to answer these two questions were selected from the script. These were "What is a typical English lesson in your group like?" and "Please describe your idea of an ideal English lesson.". In the interview these questions did not follow each other and others intervened. Codes from the original coding were examined and new analysis conducted on the basis of these.

\section{Student Voices- empirical findings}

\subsection{Analysis of the question "What is a typical English lesson in your group like?"}

This question was answered by all the students in the sample. In the original analysis 55 different codes were used to describe activities or topics mentioned and these codes were employed a total of 2961 times. In the new analysis these were re-grouped to eliminate overlap and to provide greater clarity. Information about how this was done is given below in the analysis of the interview question.

\subsubsection{Work with the coursebook}

Information connected with use of the coursebook was most frequently mentioned by learners, composing $19.4 \%$ (575) of all instances where codes were used. One new code was created and labelled Work with the coursebook, which was composed of 4 original codes ('work with the coursebook'; 'we do exercises'; 'exercises'; and 'exercises from the book or recording'). Sample participant opinions are given below:

Most often we do exercises and everyone does them by themselves and then we check them together as a class and then we correct the mistakes (all quotations from the data are the author's translations)

And so it's like this, we talk about, for example, a reading text from the coursebook and everything is connected. For example, in the reading there are various bits of grammar, such as past tenses and we do lots of exercises. There are lots of exercises in the work book and we also do a few in our notebooks. 


\subsubsection{Skills}

The next most frequently used codes were connected with skills, comprising $16.4 \%$ of the instances of codes used. Again original codes were amalgamated; Listening consists of the original codes 'listening to recordings' (43 instances), ' dictation' (3), 'watching films' (8), and 'songs' (7), a total of 61 instances. Speaking is made up of 'dialogues and talking in English' (51), 'talking about pictures' (3), 'questions and answers' (24), a total of 78 instances. Writing includes the codes 'writing' (45) and 'writing in our notebooks' (72), a total of 117 instances. Reading is composed of 'reading' (161), and 'translating the text into Polish' (70), a total of 231 instances.

According to the learners, reading and writing predominate in lessons, comprising $71.4 \%$ (348) of all the instances of use of codes referring to skills (487), while skills associated with oral communication (speaking and listening) make up $28.5 \%$ (131).

Other types of exercises mentioned by learners were vocabulary (153 instances, 5,2\%) and grammar (99 instances, 3.3\%) comprising $8.5 \%$ of all the instances of codes used to describe a typical lesson. On this level, reading tops the list for frequency at $7.8 \%$, followed by vocabulary at $5.2 \%$, writing at $3.9 \%$, grammar at $3.3 \%$, speaking at $2.6 \%$ and listening at $2.1 \%$.

\subsubsection{Other frequently occurring codes}

The next set of codes refers to Teacher activity, including the codes 'Teacher writes on the board' (21 instances) and 'Teacher explains the topic of the lesson' (145). Together these codes comprise 5.6\% of all instances of codes used. Homework, covering the codes 'Checking homework' (65 instances), 'Teacher sets homework' (49), and 'Checking with the teacher' (40) accounts for $5.4 \%$ of the codes used. The final set of most frequently used codes, totalling 3.4\%, refer to Assessment with 'speeches' (35 instances), 'quizzes' [pol. kartkówki] (24) and 'tests' (4).

To sum up, from the learner perspective, English lessons appear to focus predominantly on the coursebook, with traditional activities such as reading, writing, and exercises in vocabulary and grammar most often mentioned. Homework appears to be an integral part of the lesson and the teacher is actively engaged in explaining the topic of the lesson. Assessment also appears as a frequent mention. 


\subsection{Analysis of "Please describe your idea of an ideal English lesson".}

Answers to this question were given by 460 of the 480 learners in the sample. The remaining 20 responded only "I don't know". 106 different codes were used in the original analysis, applied 1644 times. As with the previous question new code categories were created for this paper.

\subsubsection{The process of learning}

The first set is labelled Process of learning and comprises $38.7 \%$ (66) of all the codes used to describe responses to this question. Within this code set there are two sub-groups: More active and More effective and more interesting teaching comprising $29.4 \%$ and $24 \%$ respectively of the 636 Process code instances.

\section{More active lessons}

The sub-group More Active includes the original codes 'Discussion, conversations in English' (47 instances), 'work in groups' (40), 'Educational games' (39), 'more exercises' (30), 'interesting projects' (18), 'Learners make posters' (7), 'speaking only in English' (5), and 'Learners think of the topic for a lesson' (1), making a total of 187 instances. The most representative opinions in the More Active code group follow:

If we worked more in groups we would learn more from our friends and everyone would be able to give their opinion.

It's really lessons in groups that are the best for me because you can communicate in English with other people in the class too, not just you with yourself, like when you're reading, right? And I think it integrates the whole class and it's easier to communicate in the foreign language than in... If you go away somewhere, well then it would be easier to communicate. Even if you don't know some words you can always explain in your own words, but in front of the teacher there's always pressure, but with your peers it's less.

Learners are able to articulate the benefits of group work, both in terms of language development, but also from the social perspective. When discussing games they also draw on a variety of arguments, such as in this quote, where the learner stresses the intellectual challenge games offer.

Some kind of game, something that's demanding, it's a game but it also makes you think, yes? That would be great. 
Others see games as an opportunity to change the structure of the lesson, to add variety, or to allow movement.

Something like, you stand up in the middle of the room, that sort of thing, because some of the exercises [we do] are monotonous.

So that we didn't have to sit in our places like we usually do, only, I don't know, in a circle and do some group-building activities [pol. zabawy integracyjne] and not just writing.

Some students see games as helping learning become more memorable, or that they would be actively involved in using the target language.

We could do something like presenting stories. Some interviews with each other. And on the basis not just of writing, but also explaining with some kind of demonstration [pol. pokazywaniem], as if it was a game, so it would be better to remember.

Well I think actually that there could be a few more games of some sort. Of course I'm not saying that they should be very frequent, but from time to time,... yes that's it, that we could talk in English sometimes, some day for example that we only speak in English and I think that would be nice, great.

\section{More effective and interesting teaching}

More effective and more interesting teaching includes the codes 'lots of additional materials' (65), 'division into groups according to ability' (20), 'more effectively' (13), 'contact with native speakers' (12), 'words taught thematically' (12), 'information about English-speaking countries' (10), 'learning with songs' (8), 'learning useful things' (3), 'invited guests' (3), which covered a total of 153 instances.

It can be seen from analysis of codes in this section that learners appear to perceive a need to be more actively engaged in the learning process. They dream of more variety during lessons, both in terms of materials, but also as far as activities and organization are concerned.

\subsubsection{The ideal English teacher}

Apart from the process of learning, 246 students (51.1\%) also talked about their idea of an ideal English teacher. This was analyzed using 25 codes, of which 470 instances were noted, representing $28.6 \%$ of all the codes used to answer the question about the ideal lesson. The codes were divided into 
three sets, Teacher activity, (32.1\% of all instances of codes about the ideal teacher) Teacher Character (25.3\%) and Teacher supports learners (29.8\%).

The set Teacher activity covers a variety of codes. These include codes about language and language use ('speaks English in the lesson' (52), 'speaks Polish' (14), 'knows English well' (5); about motivational strategies ('demands enough from us' (29), 'encourages and motivates' (7), 'does not give negative grades' (4); about the way the lesson is run ('gives interesting lessons' (23), 'really tries hard' (7); and about classroom management ('keeps discipline in the lesson' (10), It is of note that the most frequently used codes express a wish that English be used in the lesson (34.4\% of the instances of codes in this set) and that the teacher demands enough of the learners (19.2\%).

As for Teacher Character, learners would like their ideal teacher to be 'nice and calm' (63), 'understanding' (22), 'have a sense of humour' (8), 'not to shout' (12), 'not to have favourites' (7), and 'to assess fairly' (7).

With regard to Teacher supports learners the most frequently occurring code, representing $70 \%$ of the instances of codes about the ideal teacher, was 'teacher explains everything' (98). This was followed by 'teacher repeats' (21), 'teacher has a lot of time for learners' (17). The set also included teacher 'helps' (2) and 'corrects' (2).

For the learners who spoke about their ideal teacher it would appear that they feel a need for more support, particularly in the form of explanations and a calm and understanding person who speaks English during the lesson.

\subsubsection{The ideal group in which to learn English}

The final set of codes which will be described concerns learners' views on the ideal group they would like to have for English. This topic was raised by 227 (47.3\%) of the sample and was coded using 13 codes, applied 341 times, which was $20.7 \%$ of all the instances of codes used to answer the question about the ideal lesson. Most frequently mentioned was 'a nice atmosphere' (121 instances) 'without quarrels' (9). Codes connected with atmosphere accounted for $38.1 \%$ of all the codes about the ideal group. $28.4 \%$ of the codes about the ideal group described characteristics such a group should have. Of these the most frequent, representing $53.6 \%$ of instances of the codes from this sub-set, was that the group 'is quiet' (52), followed by 'works cooperatively' (25), is 'harmonious' (11), 'prompts weaker learners' (5), and 'does not laugh at others' (4). The final sub-set, representing $13.2 \%$ of the codes about groups, was about organization where the most frequent codes were 'a similar level in the group' (27) and 'small groups' (18). 
The codes about the ideal learning group for English appear to reflect a desire from learners for a group which is homogeneous in terms of level of ability, with a positive atmosphere, and where there are good relationships with their peers. $7.5 \%$ (124 instances) of all instances of codes used to answer the question about the ideal English lesson expressed satisfaction with the students' current learning situation, as they stated 'like it is now' in response to the question.

\section{Discussion and reflections}

In this section we will compare and contrast what has been discovered about typical lessons of English in school from the learners' descriptions with how learners imagine an ideal lesson. In this way it is hoped we can obtain a new perspective on teaching and learning in lower secondary schools.

\subsection{The learning process}

From descriptions of current lessons we found that learners see what happens in school English lessons as strongly based around work with the coursebook, with a focus on doing exercises practising reading, vocabulary, writing and grammar. In their imagined lessons learners appeal to be given the opportunity to be more actively engaged in the learning process, expressing a desire for more active use of the target language through discussions and group work, where everyone would have the chance to speak and take part in the lesson. They suggest that educational games could be used to challenge and stimulate them, and that these would offer a welcome change in the lesson and offer them the chance to speak. They understand that through active engagement learning becomes more memorable. It would therefore seem that some learners at present do not feel that their lessons of English are offering them the opportunities to use the language, which they perceive as key in the process of foreign language learning. They also appeal that the teacher should use the target language. According to the learners, language use in class appears to mean doing exercises from the coursebook, while they would prefer this to involve communication and interaction.

This impression about the dominance of the coursebook is reinforced when we look at what learners say about their ideal teacher. While opinions of English teachers they currently have are in general positive, the learners dream of having a teacher who works with them to help them understand the material thoroughly, through giving explanations. This suggests that they 
would like more opportunities to be able to say what is not clear and to ask questions, rather than simply do written exercises. Although they report appreciatively that their teachers do a great deal for them and try hard, this suggests that the learners are in fact passive in the classroom, rather than actively engaged. It is difficult to develop communicative skills if it is the teacher who is active, rather than the learner.

It is of note that despite their age, all learners were able to describe what they usually do during lessons, although these descriptions are often quite general and rarely voiced in terms of what lessons aim to teach. By contrast, it was harder for some learners to give their imaginations free rein, as reflected by the fact that not all learners answered the question about their ideal lesson. We have seen that learners have a wealth of constructive ideas on how learning English could be improved and given encouragement could become more involved in the planning process. We have also seen that some pupils are able to question whether what is being done now is as effective as it could be. As critical thinking is one of the key competences in the Core Curriculum which should be developed across all school subjects, it would seem that this type of activity could be used by teachers to work on this skill. The information obtained and the processes involved, as the research literature on Student Voice evidences, could be beneficial both for the teacher and the learners.

\subsection{The learning group}

Learners were able to clearly describe social aspects of lessons which disturb the learning process and in their descriptions of the ideal group suggest ways in which these could be tackled. If there are behavior problems in a group these learners seem to be suggesting that if only the teacher would share the responsibility for keeping discipline with them, then the group would find a solution. This quotation from a young American student eloquently puts this into words:

Reach me with more than words from textbooks-but words from the soul and the mind connected to the heart. What got you to teach me? Wasn't it to reach me? ... Relate to me, debate with me, respect me. Stop neglecting me. (Strucker et al., 2001:162)

\section{Conclusions}

We have seen that offering learners the chance to talk about the teaching and learning of English in lower secondary schools can give important in- 
sights into how they perceive English is taught and how this could be changed. Although the sample used to obtain the data in this study is not representative, it is large and comes from 120 different schools across the country. Consequently, with caution, we may infer that what learner say here may be fairly typical of the opinions of learners in the first class of gimnazjum. There remain then two important issues which need to be addressed. The first of these is best expressed in the following quotation: "we are all enriched through the process of authentically listening- provided we not only listen, but also hear and act" (Czerniawski \& Kidd 2011:xxxvii)

What then can be done in response to the picture of the process of teaching English which is presented here? The question of the role of the coursebook in the teaching of foreign language is the one which needs widespread debate. Learners are claiming that the coursebook dominates lessons and that it is the traditional skills of reading and written exercises on vocabulary and grammar which predominate in the typical lesson. They appeal for more chances to use the target language and more use of it by the teacher. It is not difficult to infer from this that certain aspects of the Core Curriculum, such as speaking and listening, appear to be under-represented in school. This is a serious problem. If the main goal of teaching in secondary schools is to enable "effective spoken and written communication in the foreign language" (MEN 2009:61, own translation), then, from what learners appear to be suggesting, it would appear that the basic conditions for this to come about are not being met. Effective spoken communication is not developed through doing written exercises. Response is needed in the form of discussion and reflection and also by encouraging teachers to listen to their own learners, with the view of obtaining a different perspective and look for possible ways forward.

Responding to critical information which has been obtained from the voices of learners is, however, challenging as it requires "major shifts on the part of teachers, students, and researchers in relationships and in ways of thinking and feeling about the issues of knowledge, language, power, and self" (Oldfather, 1995, p. 137). This means that we need to value the opinions of the learners given here in the same way that we currently value the results of national examinations. Responding only to test scores means that we are evaluating only the product of the school, but not the process from which that came. Student voice offers important insights into that process.

Within Polish education the legislation exists to really give pupils and young people a voice and fully engage learners in the democratic process of educational improvement. It is simply a question of really implementing this and making it work. 
Finally, it needs to be remembered that learning a language effectively means being able to use it in a wide range of situations. This is not the same as being able to do written exercises from a coursebook. A coursebook is a tool to support the educational process, not a substitute for it.

\section{Acknowledgements}

This research was financed by the European Union under the European Social Fund- Operational Programme Human Capital, Priority III- High quality of education; within the grant "Quality and effectiveness of educationstrengthening of institutional research capabilities" Section 3.1.1 Creating conditions and tools for monitoring, evaluating and researching the educational system. A large number of people from Educational Research Institute were involved in the research, including Karolina Babak, Dorota Campfield, Katarzyna Kutyłowska, Katarzyna Pacuszka and Kamil Sijko. The views expressed here are those of the author.

\section{BIBLIOGRAPHY}

Bragg, S., 2007. Consulting young people: a review of the literature London: Creative Partnerships.

Cook-Sather, A, 2002. "Authorising students' perspectives: toward trust, dialogue, and change in education". Educational Researcher. 31/4: 3-14.

Czerniawski, G and Kidd, W. 2011. The Student Voice Handbook: Bridging the academic/practitioner divide. Bingley: Emerald Group Publishing.

Czyż, E. (n.d.) Prawa ucznia w szkole. Warszawa: Helsińska Fundacja Praw Człowieka. Retrieved from www.bezuprzedzen.org/doc/Prawa_ucznia_w_szkole_HFPCz.pdf on 30.09.2013.

Flutter,J. and Ruddock, J. 2004. Consulting pupils: What's in it for schools? London: Routledge Falmer.

Kozol, J. 1991. Savage inequalities: Children in America's schools. New York: Harper Perennial. Ministerstwo Edukacji Narodowej. 1992. Zarzqdzenie nr. 14 z dnia 19.06.1992 w sprawie ramowych statutów szkół publicznych.

Ministerstwo Edukacji Narodowej. 2009. Postawa Programowa z komentarzami. Języki Obce.

Oldfather, P. 1995. "Songs "come back most to them": Students' experiences as Researchers". Theory into Practice, 43 (2):131-137.

Rudd, T., Colligan, F., and Naik, R., 2007. Learner Voice: A Handbook. Bristol: Futurelab. Ruddock, J. 2004. Pupil voice is here to stay! Retrieved from http://www. serviceschoolsmobilitytoolkit.com/resourcedownloads/staffroom/bpv_thene edtoinvolvepupilvoice.pdf on 30.09.2013

Ruddock, J. and Flutter, J. 2004. How to improve your school: giving pupils a voice, London: Continuum. 
Melanie Ellis

Strucker, M., Moise, L. N., Magee, and V. L., Kreider, H. 2001. "Writing the wrong: Making schools better for girls" (w:) In our own words: Students' perspectives on school. J. Shultz i A. Cook-Sather (red.) Lanham, MD: Rowman \& Littlefield: 149-164. 